\title{
Reproductive pattern of the large fruit-eating bat, Artibeus amplus (Chiroptera: Phyllostomidae) in the Venezuelan Andes
}

\author{
Damián Ruiz-Ramoni ${ }^{1,2}$, Paolo Ramoni-Perazzi ${ }^{1,3}$ \& Mariana Muñoz-Romo*1 \\ 1. Laboratorio de Zoología Aplicada, Departamento de Biología, Facultad de Ciencias, Universidad de Los Andes, \\ Mérida, Venezuela; mariana@ula.ve \\ 2. Current address: Instituto Venezolano de Investigaciones Científicas (IVIC) Laboratorio de Paleontología - Centro \\ de Ecología, Km 11 Carretera Panamericana, Estado Miranda, apartado 21.827, código postal 1020-A - Caracas - \\ Venezuela; drramoni@gmail.com \\ 3. Centro de Simulación y Modelos (CESIMO), Facultad de Ingeniería, Universidad de Los Andes, Mérida, Venezuela; \\ rpaolo@ula.ve \\ * Correspondence
}

Received 18-IV-2016. Corrected 14-X-2016. Accepted 19-X-2016.

\begin{abstract}
Bimodal polyestry is the most common reproductive pattern in tropical bats, and it consists in producing one offspring per female twice a year. Reproductive patterns are closely related to rainfall regimes, frequently occurring twice a year in tropical regions. The goal of our study was to determine the reproductive pattern of the large fruit-eating bat, Artibeus amplus Handley, 1987 in a cave in the Venezuelan Andes inhabited by a large, stable colony. Thus, in this study we describe for the first time this important biological aspect of this unknown Neotropical bat species through the examination of external reproductive characteristics of males (inguinal or scrotal testes) and females (pregnant, lactating, post-lactating), based on 211 individuals (120 males and 91 females) captured between September 2008 and August 2009, in Cueva del Parque Las Escaleras, Estado Táchira, Venezuela. During this period of monthly sampling for a full year, most males displayed large scrotal testes, averaging $10 \mathrm{~mm}$ maximum length. The examination of females indicated that although pregnancy was first observed in November 2008, it reached a maximum during January and February 2009. Although adult males with scrotal testes throughout the year could imply that females have more than one pregnancy, our results suggested a seasonally monoestrous reproductive pattern for $A$. amplus. This study represents the first report of reproductive pattern for this poorly-known Neotropical frugivorous species. The observed monoestrous reproductive pattern supports the existence of synchronization between precipitation and reproduction. This synchronization has been frequently observed in most species of fruit bats. In this study, Artibeus amplus presumably adjust the parturition to anticipate the rainy season, as a strategy that allows maintenance of offspring during high availability of fruits. Rev. Biol. Trop. 65 (1): 335-344. Epub 2017 March 01.
\end{abstract}

Key words: bat, reproductive pattern, rainfall, monoestrus.

The most common reproductive pattern in tropical bats is bimodal polyestry (Wilson, 1979; Racey, 1982; Racey \& Entwistle, 2000), which consists in producing one offspring per female twice a year. Although the control of reproductive patterns is driven by hormonal changes in females (Bronson, 1985; Brown, 1999; Martin \& Bernard, 2000), a common strategy in males is to remain fertile throughout the year once they reach adulthood (Racey, 1982). In frugivorous bats, it has been determined that reproduction is closely related to food availability, which in turn depends on climatic conditions such as temperature and precipitation (Wilson, 1979; Racey, 1982; Heideman, 2000). Thus, bimodal polyestry is closely related to a rainfall regime that occurs twice a year (Wilson, 1979; Racey, 1982; Racey \& Entwistle, 2000).

Studies on reproductive patterns are available for several species of Neotropical bats, and particularly in Phyllostomidae this bimodal 
seasonal polyestrous pattern is frequent: Carollia perspicillata (Fleming, 1988; Mello \& Fernández, 2000), C. brevicauda and eight other frugivorous bats of the genera Sturnira, Artibeus, Dermanura, Enchisthenes, and Platyrrhinus (Molinari \& Soriano, 2014), A. jamaicensis (Wilson, Handley, \& Gardner, 1991; Ortega \& Castro-Arellano, 2001), A. jamaicensis and A. lituratus (Sosa \& Ramoni-Perazzi, 1995), and Glossophaga longirostris (Sosa, 1991; Sosa \& Soriano, 1996). However, it is well known that variations may exist due to specific climatic conditions at each study site (Wilson, 1979; Racey, 1982; Bronson, 1985; Estrada \& Coates-Estrada, 2001). For example, monoestrous patterns have been observed in commonly "polyestrous" species, such as $A$. lituratus in Southeast Brazil (Duarte \& Talamoni, 2010), an area characterized by a single maximum rainfall period.

The large fruit-eating bat Artibeus amplus (Handley, 1987), one of the largest species of Artibeus, is one of the poorest-known Neotropical species (Lim, Genoways, \& Engstrom, 2003). Although an assessment based on its geographic distribution assigned this species to the Least Concern category (Ramoni-Perazzi, Ruiz-Ramoni, Muñoz-Romo, Thielen Engelbertz, \& Soto Werschitz, 2014), the lack of information regarding its biology and population trends, and its scattered distribution (Ramoni-Perazzi, Muñoz-Romo, Chaves, \& Kunz, 2012), mainly restricted to caves (Medellin \& Shipper, 2009), could make $A$. amplus one of the most threatened species of Neotropical bats in specific locations.

In Venezuela, A. amplus has been found in a few roost sites and we were aware of a large, stable colony in one of them. We hypothesize that the reproductive pattern of $A$. amplus will reflect a clear relationship with the rainfall regime of the study site (a single maximum yearly), and this may result in a different pattern from most Artibeus species (i.e., bimodal polyestry). Thus, the goal of our study was to determine the reproductive pattern of the large fruit-eating bat, in a cave in the Venezuelan Andes inhabited by a large, stable colony.
Reproductive data presented here constitute the first study to describe this primordial aspect of the biology of this unknown species of Neotropical bat.

\section{MATERIALS AND METHODS}

Study species: $A$. amplus is distributed in Colombia, Venezuela, Guyana and Suriname (Ramoni-Perazzi et al., 2012) and is associated with forested habitats (Handley, 1987; Linares, 1998; Lim et al., 2003; Ramoni-Perazzi et al., 2014). This fact, as well as its phylogenetic affinities and morphological similarities with other large Artibeus (i.e., A. jamaicensis and $A$. lituratus) suggest a frugivorous diet (Handley, 1987; Linares, 1998). In fact, recent evidence indicated that leaves and insects also seem to be important items in its diet (Ruiz-Ramoni, 2010; Ruiz-Ramoni, Muñoz-Romo, RamoniPerazzi, Aranguren, \& Fermin, 2011), as in other frugivorous.

Study site: The studied population of A. amplus was found in Cueva del Parque

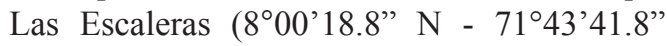
W, 1320 masl), approximately $4 \mathrm{~km} \mathrm{SE}$ of Pregonero town, Municipio Uribante, Estado Táchira, Venezuela (Fig. 1). The cave is frequently visited by people because it is located within the recreational park. The vegetation of the area mainly consist of human-disturbed habitats, as well as open savanna of oligotrophic origin, and small patches of secondary forest surrounding rivers and creeks (RamoniPerazzi et al., 2014). Monthly mean temperature of the study site is $20^{\circ} \mathrm{C}$ (Molina-Chacon, 1983). Annual precipitation averages 1636.9 $\mathrm{mm}(\mathrm{n}=49$ years, from the National Institute of Meteorology and Hydrology; INAMEH, http:// www.inameh.gob.ve), occurring in a unimodal pattern, with a period of drought from January to March, and a period of water availability the rest of the year, with maximum in July and August (Molina-Chacon, 1983). The cave is $c a .38 \mathrm{~m}$ long and it is divided into three consecutive chambers. Individuals of $A$. amplus occupied the second and third chambers 


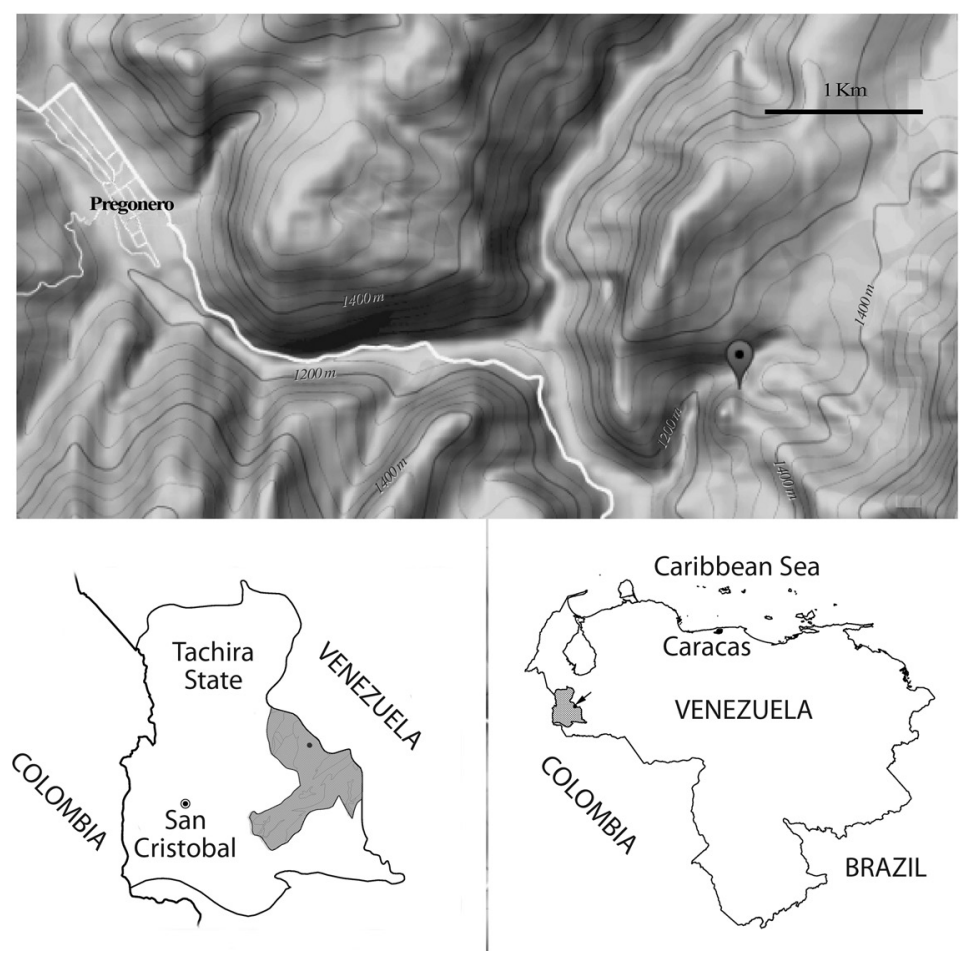

Fig. 1. Location of the study area in the Venezuelan Andes. Top: area of Municipio Uribante indicating the location of Pregonero town and Cueva de Las Escaleras, topography according to RgoogleMaps (Loecher and Ropkins, 2015); bottomleft: map of Tachira State highlighting Municipio Uribante; bottom-right: map of Venezuela highlighting Tachira State.

(ca. $21 \mathrm{~m}$ from cave entrance), both about $2.5 \mathrm{~m}$ in height.

Sampling of individuals: All sampling protocols were performed following guidelines of the American Society of Mammalogists for capture, handling, and care of mammals (Sikes, Gannon,\& the Animal Care and Use Committee of the American Society of Mammalogists, 2011). Bats were captured monthly from September 2008 to August 2009, inside the cave between 13:00 $\mathrm{h}$ and 17:00 h, using hand nets and mist nets (Kunz, Hodgkison, \& Weise, 2009). Individuals were examined to determine sex, body mass (Ohaus Cs 200.0 gx $0.1 \mathrm{~g}$ ), and standard body measurements (Spi 2000 Plastic Dial Caliper $\pm 0.1 \mathrm{~mm}$ ). Age (juvenile, immature, or adult) was estimated following common criteria (Brunet-Rossinni \& Wilkinson, 2009), as well as reproductive condition (Racey, 2009). Males with scrotal testes and pregnant, lactating and post-lactating females were classified as reproductively active individuals (Racey, 2009). Post-lactating females presented large, hairless, flaccid, and dark nipples. Females lacking these characteristics were considered as non-reproductive (inactive). We are aware of the limitations of observation of external characteristics that may not be able to detect early pregnancy or actual reproductive conditions (Vela-Vargas, 2013). Maximum length of testis was also measured (Spi 2000 Plastic Dial Caliper $\pm 0.1 \mathrm{~mm}$ ) to assess changes throughout the study. Individuals were marked (Kunz \& Weise, 2009) on the right (males) or left (females) forearm using aluminum wing bands (Gey Band \& Tag Co., Norristown, PA, USA, size 4, Style 374). Finally, all individuals were released within the cave. 
Statistical analysis: Generalized linear model analyses (GLM) were used to determine whether variation in maximum length of testes was significant, controlling for body mass, and using R (R Core Team, 2015). All statistical tests considered $\alpha=0.05$. Variation in reproductive condition of males and females during the study was established by monthly percentages of bats with each reproductive condition.

\section{RESULTS}

Sampling of individuals: A total of 211 adult individuals were captured and marked (120 males and 91 females), and 74 were recaptured (56 males and 18 females). The number of males captured exceeded those of females throughout the study (except November and December 2008), ranging from 13 (September and November 2008) to 27 males (May and August 2009). Regarding females, captures ranged from two individuals (February 2009) to 18 (December 2008).

Male reproductive condition: The proportion of males with scrotal testes was greater throughout the study than that of males with non-scrotal testes (Fig. 2). The highest proportion of males with non-scrotal testes $(38.5 \%)$ was recorded in November 2008. All examined males had scrotal testes during September and December 2008, and from April to August 2009 excluding June (Fig. 2). Scrotal testes had an average length of $10.0 \pm 1.7 \mathrm{~mm}(\mathrm{n}=$ 106) (Fig. 3A). The maximum length of testes observed was $13.3 \mathrm{~mm}$, while the minimum was $4.9 \mathrm{~mm}$ (Fig. 3A). The variation in maximum length of testes showed significant

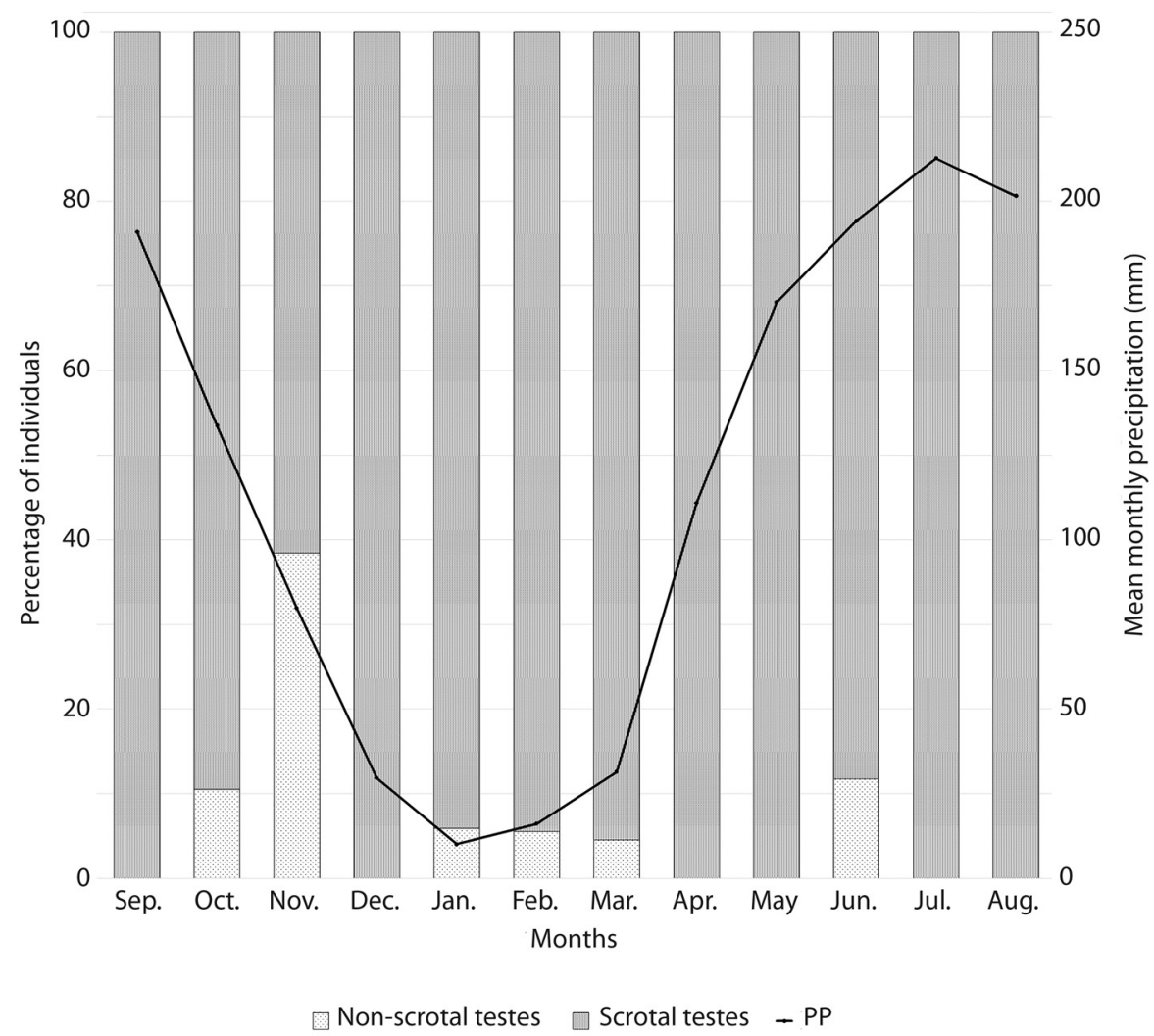

Fig. 2. Reproductive condition of adult males of Artibeus amplus $(\mathrm{n}=120)$, based on external reproductive characteristics, captured in Cueva del Parque Las Escaleras during the study. Scrotal testes (dark grey), and non-scrotal testes (light grey). 


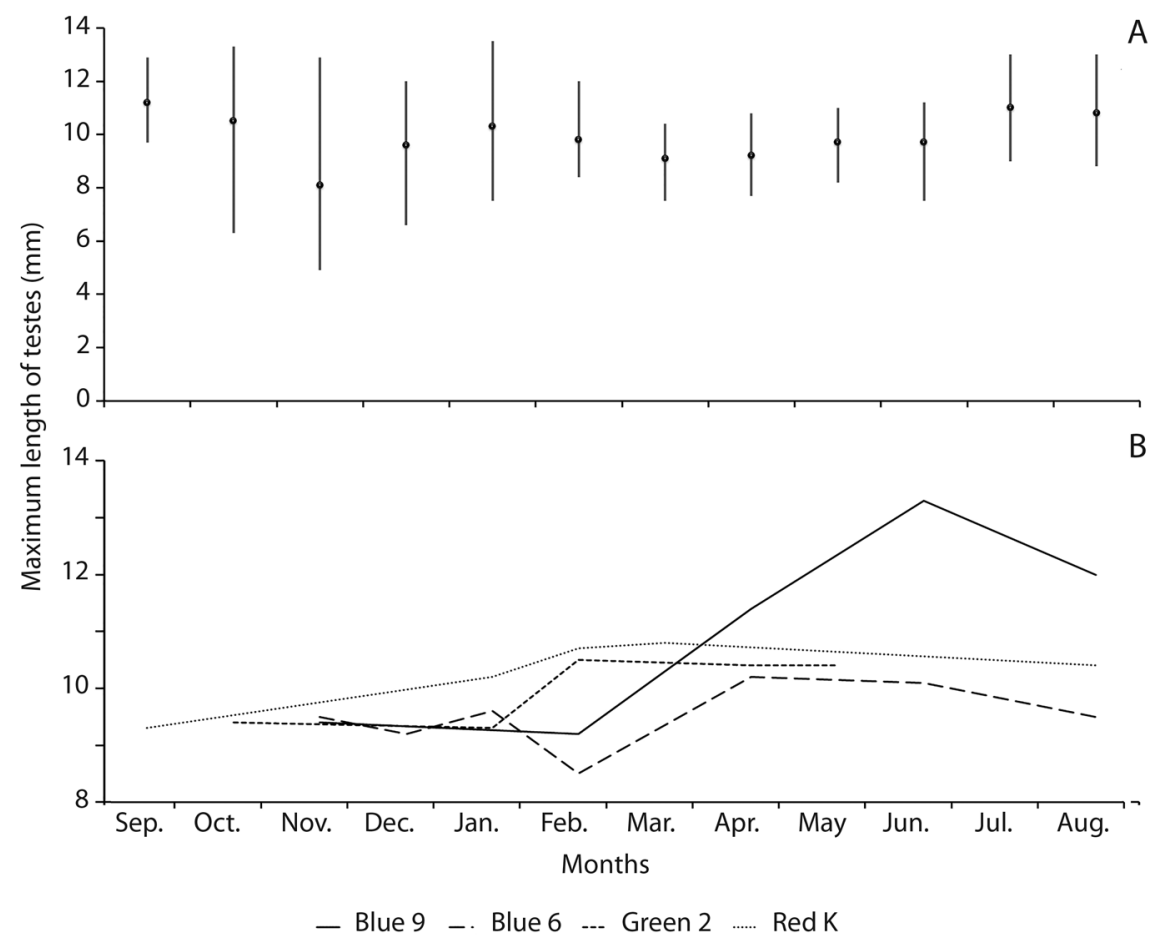

Fig. 3. A. Average of maximum length of testes of adult males Artibeus amplus during the study, and B. Variation of maximum length of testes in four frequently-recaptured individuals (Blue 9, Blue 6, Green 2, and Red K) of Artibeus amplus.

differences during the study, regarding time (GLM, $\mathrm{F}=10.527 ; \mathrm{P}<0.001$ ), and individuals (GLM, F= 2.673; $\mathrm{P}<0.001$ ). These differences are shown by four frequently recaptured males, which exhibited changes in testes length during the study period (Fig. 3B).

\section{Female reproductive condition:}

Although the variation in female reproductive condition during the study indicated first signs of pregnancy in November 2008, maximum number of pregnant individuals occurred during January and February 2009, in which all examined females were pregnant (Fig. 4). Pregnant females were observed from November 2008 to May 2009, and the lowest observed proportion was $9 \%$ (April 2009). After the period of maximum pregnancy (January-February 2009), lactating (Fig. 5) and post-lactating females were briefly observed (Fig. 4). The highest observed proportion of post-lactating females was $27.8 \%$ (October 2008). After the period of maximum pregnancy (January to March 2009), the capture of pregnant females decreased abruptly. All captured females were considered reproductively inactive in June and August 2009 (Fig. 4).

\section{DISCUSSION}

Most males of $A$. amplus at Cueva del Parque Las Escaleras had scrotal testes. This permanent testicular descent has frequently been observed in other Artibeus such as A. jamaicensis and $A$. lituratus in an arid region of the Venezuelan Andes (Sosa \& RamoniPerazzi, 1995), and in A. lituratus in Brazil (Duarte \& Talamoni, 2010). These last authors also examined testicular activity through spermatogenic analysis and indicated that males were reproductively active and fertile throughout the annual cycle. Maintaining scrotal testes 


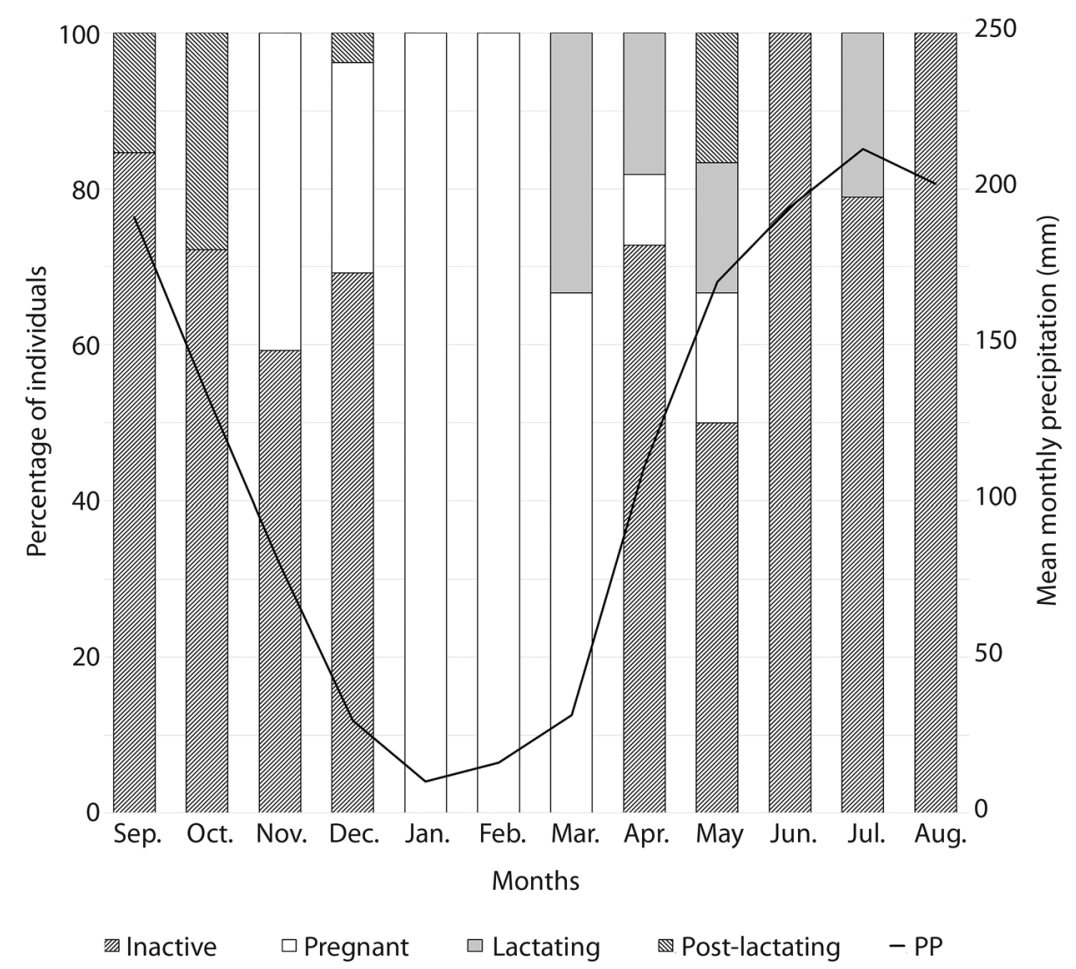

Fig. 4. Reproductive condition of adult females of Artibeus amplus $(\mathrm{n}=91)$, based on external reproductive characteristics, captured in Cueva del Parque Las Escaleras during the study. Inactive (striped lines, ascend), pregnant (white), lactating (grey), and post-lactating (striped lines, descend). Solid line indicates precipitation ( $\mathrm{mm})$.

throughout the year ensures availability of sexually mature males to reproduce anytime during the reproductive cycle (Bronson, 1985; Krutzsch, 2000; McCracken \& Wilkinson, 2000), although the cost of this condition requires high energy (Krutzsch, 2000; Speakman, 2008). The presence of male A. amplus able to reproduce anytime during the annual cycle in our study area is probably an strategy to ensure pregnancy in this species at any time that females may come into oestrus.

The values of maximum length of testes seem to increase from February 2009 in three of the four frequently-recaptured individuals, although this trend needs further research based on extensive recaptures. Variation in maximum length of testes in the frequently-recaptured males reinforces the generalized linear model analyses with regards to the existence of significant monthly variation of testes lengths, with different trajectories for each individual, which might suggest differences between males, but this trend needs further research.

We are aware of the limitations inherent to the examination of external reproductive characteristics, as these might not be sufficiently informative to detect early stages of females' reproductive cycle (Vela-Vargas, 2013). The only reproductive event observed (i.e., maximum pregnancy during the driest period in January-February) indicated a monoestrous reproductive pattern for A. amplus at Cueva del Parque Las Escaleras. Reproductive events are frequently synchronized to climate (Opler, Frankie, \& Baker, 1980; Sobral \& Machado, 2001). This synchronization of reproduction with maximum rainfall, frequently reported in tropical regions of South America, has been observed in most species of fruit bats (Willig, 1985; Dinerstein, 1986; Duarte \& Talamoni, 


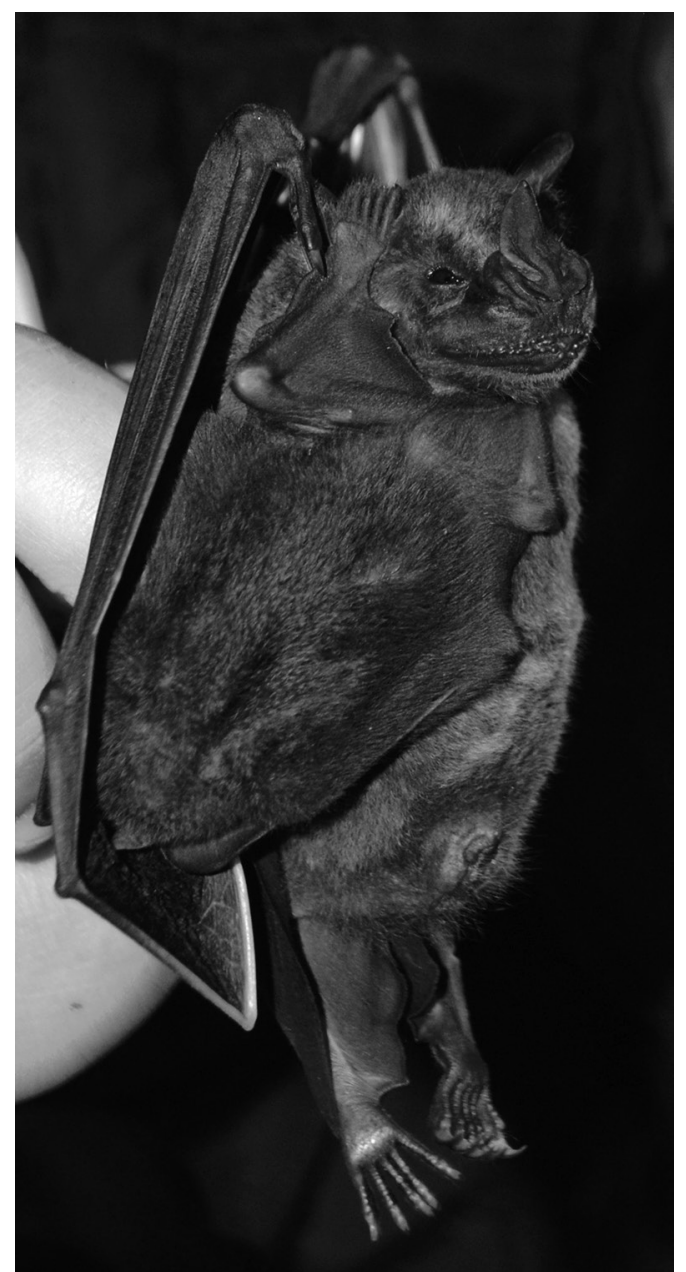

Fig. 5. Female Artibeus amplus with an infant, captured at Cueva del Parque Las Escaleras on March 28, 2009. Note fingers of researcher as size reference.

2010), with most species exhibiting a polyestrous reproductive pattern (Wilson, 1979; Willig, 1985; Molinari \& Soriano, 2014). However, monoestrous patterns, such as that observed in this study, have also been reported for Neotropical frugivorous species such as A. lituratus (Duarte \& Talamoni, 2010) and Anoura geoffroyi (Baumgarten \& Vieira, 1994; Zortéa, 2003) in populations subject to unimodal rainfall regimes in Brazilian localities.

The Venezuelan Andes are an orographic barrier between two regimes of precipitation
(Monasterio \& Reyes, 1980): the Llanos versant has the unimodal rainfall pattern typical of the North of South America, as described in Hastenrath (1984), while the Maracaibo Lake versant has the bimodal pattern, typical of the Caribbean region as described in Taylor and Alfaro (2005). Here, our results highlighted the existence of synchronization between precipitation and reproduction at least among large-size Artibeus species, on both sides of this Cordillera. The monoestrous pattern observed here for A. amplus on the Llanos versant contrasts with those polyestrous patterns reported by Sosa and Ramoni-Perazzi (1995) in a locality on the Maracaibo Lake versant, where rainfall has two peaks in April-May and September-October, $A$. jamaicensis showed reproductive maxima in May and in October, and A. lituratus showed reproductive maxima in March and July (Sosa \& Ramoni-Perazzi, 1995).

In this study, Artibeus amplus presumably adjust the parturition to anticipate the rainy season, as a strategy that allows maintenance of offspring during high availability of fruits (Fleming, Hooper, \& Wilson, 1972). In the study area, A. amplus could be favoring the greatest survival rate for the offspring, since the critical lactation period would then occur at a time of maximum food availability.

This study supported not only a clear relationship of reproduction with rainfall regimes, but also provides the first report of reproductive pattern of a Neotropical bat species that has remained unknown since its discovery, back in 1987. However, several aspects of its biology still remain to be determined. Some of these could be the detailed study of reproductive conditions of males and females based on the examination of hormonal profiles and histological conditions of their reproductive tracts, and the determination of whether giving birth to a single offspring/year in $A$. amplus in the study site is related to delayed development, which was reported in other large Artibeus (Fleming, 1971). Finally, does seasonal polyestry could occur in A. amplus under different rainfall regimes, as in other large Artibeus? 


\section{ACKNOWLEDGMENTS}

We want to thank to G. Bianchi, L. M. Otero, A. Duque-Márquez, M. Merida, Y. Ramoni-Perazzi, J. Burgos, D. Galíndez-Malavé and V. Chaparro-Urbina for their support with fieldwork.

\section{RESUMEN}

Patrón reproductivo del murciélago frugívoro grande, Artibeus amplus (Chiroptera: Phyllostomidae) en los Andes venezolanos. Poliestría bimodal es el patrón reproductivo más común en murciélagos tropicales, y consite en producir una cría por hembra dos veces al año. Los patrones reproductivos estan estrechamente relacionados con regímenes de precipitación, frecuentemente manifestándose dos veces al año en regiones tropicales. El objetivo de nuestro estudio fue determinar el patrón reproductivo del murciélago frugívoro grande, Artibeus amplus Handley 1987, en una cueva en los Andes venezolanos habitada por una colonia grande y estable. De este modo, en este estudio describimos por primera vez este aspecto biológico fundamental de esta especie de murciélago Neotropical desconocida, a través de la examinación de características reproductivas externas de machos (testículos inguinales o escrotados) y hembras (preñadas, lactantes o postlactantes), basado en 211 individuos (120 machos y 91 hembras) capturados entre septiembre 2008 y agosto 2009, en la Cueva del Parque Las Escaleras, en Táchira, Venezuela. Durante este período de muestreo mensual por un año, la mayoría de los machos mostraron testículos escrotados grandes, con promedio de $10 \mathrm{~mm}$ de longitud máxima. La examinación de las hembras indicó que aunque la preñez fue observada por primera vez en noviembre 2008, esta alcanzó su máximo durante enero y febrero 2009. Aunque la presencia de machos adultos con testículos escrotados a lo largo del año podría implicar que las hembras experimentan más de una preñez, nuestros resultados sugieren un patrón reproductivo monoestro estacional para A. amplus. Este estudio representa el primer reporte de patrón reproductivo para esta especie de frugívoro neotropical desconocido. El patrón reproductivo monoestro observado apoya la existencia de una sincronización entre precipitación y reproducción. Esta sincronización ha sido frecuentemente observada en especies de murciélagos frugívoros. En este estudio, Artibeus amplus presumiblemente ajusta el parto anticipando la estación lluviosa, como una estrategia que permite el mantenimiento de las crías durante la disponibilidad máxima de frutas.

Palabras clave: murciélago, patrón reproductivo, monoestro, Artibeus amplus, Venezuela.

\section{REFERENCES}

Baumgarten, J. E., \& Vieira, E. M. (1994). Reproductive seasonality and development of Anoura geoffroyi (Chiroptera: Phyllostomidae) in central Brazil. Mammalia, 58, 415-422. DOI: 10.1515/mamm.1994.58.3.415

Bronson, F. H. (1985). Mammalian reproduction: an ecological perspective. Biology of Reproduction, 32, 1-26. DOI: $10.1095 /$ biolreprod32.1.1

Brown, T. (1999). Steroid hormones, overview. In E. Knobil, \& D. J. Neill (Eds.), Encyclopedia of Reproduction (Vol. 4, pp. 634-644). San Diego: Academic Press.

Brunet-Rossinni, A. K., \& Wilkinson, G. S. (2009). Methods for age estimation and the study of senescence in bats. In T. H. Kunz, \& S. Parsons (Eds.), Ecological and behavioral methods for the study of bats ( $2^{\text {nd }}$ ed., pp. 315-325). Baltimore: The Johns Hopkins University Press.

Dinerstein, E. (1986). Reproductive ecology of fruit bats and the seasonality of fruit production in a Costa Rican cloud forest. Biotropica, 18, 307-318. DOI: $10.2307 / 2388574$

Duarte, A. P. G., \& Talamoni, S. A. (2010). Reproduction of the large fruit-eating bat Artibeus lituratus (Chiroptera: Phyllostomidae) in a Brazilian Atlantic forest area. Mammalian Biology, 75, 320-325. DOI: 10.1016/j.mambio.2009.04.004

Estrada, A., \& Coates-Estrada, R. (2001). Species composition and reproductive phenology of bats in a tropical landscape at Los Tuxtlas. Journal of Tropical Ecology, 17, 627-646. DOI: 10.1017/S026646740100147X

Fleming, T. H. (1971). Artibeus jamaicensis: delayed embryonic development in a Neotropical bat. Science, 171, 402-404. DOI: $10.1126 /$ science. 171.3969 .402

Fleming, T. H., Hooper, E. T., \& Wilson, D. E. (1972). Three Central American bat communities: structure, reproductive cycles, and movement patterns. Ecology, 53, 555-569.

Fleming, T. H. (1988). The short-tailed fruit bat. A study in plant-animal interactions. Wildlife Behavior and Ecology Series. Chicago: The University of Chicago Press.

Handley, C. O. Jr. (1987). New species of mammals from Northern South America: fruit-eating bats, Genus Artibeus Leach. In B. D. Patterson, \& R. M. Timm (Eds.), Studies in Neotropical Mammalogy: essays in honor of Philip Hershkovitz (pp. 163-172). Fieldiana: Field Museum of Natural History. 
Hastenrath, S. (1984). Interannual variability and annual cycle: mechanisms of circulation and climate in the tropical Atlantic sector. Monthly Weather Review, 112, 1097-1106. DOI: 10.1175/1520-0493(1984)112\%3C1097:IVAACM\% 3E2.0.CO;2

Heideman, P. D. (2000). Environmental regulation of reproduction. In E. G. Crichton, \& P. H. Krutzsch (Eds.), Reproductive biology of bats (pp. 469499). Cambridge: Academic Press. DOI: 10.1016/ B978-012195670-7/50012-6

Krutzsch, H. P. (2000). Anatomy, physiology and cyclicity of the male reproductive tract. In E. G. Crichton, \& P. H. Krutzsch (Eds.), Reproductive biology of bats (pp. 92-155). Cambridge: Academic Press. DOI: 10.1016/ B978-012195670-7/50005-9

Kunz, T. H., Hodgkison, R., \& Weise, C. (2009). Methods of capturing and handling bats. In T. H. Kunz, \& S. Parsons (Eds.), Ecological and behavioral methods for the study of bats ( $2^{\text {nd }}$ ed., pp. 3-35). Baltimore: Johns Hopkins University Press.

Kunz, T. H., \& Weise, C. (2009). Methods and devices for marking bats. In T. H. Kunz, \& S. Parsons (Eds.), Ecological and behavioral methods for the study of bats ( $2^{\text {nd }}$ ed., pp. 36-56). Baltimore: The Johns Hopkins University Press.

Lim, B. K., Genoways, H. H., \& Engstrom, M. D. (2003). Results of the Alcoa Foundation-Suriname Expeditions. XII. First record of the giant fruit-eating bat, Artibeus amplus, (Mammalia: Chiroptera) from Suriname with a review of the species. Annals of Carnegie Museum, 72, 99-107.

Linares, O. J. (1998). Mamíferos de Venezuela. Caracas, Venezuela: Sociedad Conservacionista Audubon de Venezuela \& British Petroleum.

Loecher, M., \& Ropkins, K. (2015). RgoogleMaps and loa: Unleashing R Graphics Power on Map Tiles. Journal of Statistical Software, 63(4), 1-18. Retrieved from http://www.jstatsoft.org/v63/i04/

Martin, L., \& Bernard, T. F. (2000). Endocrine regulation of reproduction in bats: The role of circulating gonadal hormones. In E. G. Crichton, \& P. H. Krutzsch (Eds.), Reproductive biology of bats (pp. 27-64). Cambridge: Academic Press. DOI: 10.1016/ B978-012195670-7/50003-5

McCracken, G. F., \& Wilkinson, G. S. (Eds.). (2000). Bat mating systems. Reproductive biology of bats (pp. 321-362). New York, Academic Press. DOI: 10.1016/ B978-012195670-7/50009-6

Medellin, R., \& Shipper, J. (2009). IUCN Red List Threatened Species (2009): Artibeus amplus. (Electronicbased document). United Kingdom. Retrieved from http://www.iucnredlist.org/apps/redlist/details/2121/0
Mello, M. A. R., \& Fernández, F. A. (2000). Reproductive ecology of the bat Carollia perspicillata (Chiroptera, Phyllostomidae) in a fragment of the Brazilian Atlantic coastal forest. Mammalian Biology, 65, 340-349.

Molina-Chacón, A. J. (1983). Ecología regional de la cuenca alta del río Uribante: contribución a un método para el estudio integral del medio andino venezolano (Tesis de Maestría). Universidad de Los Andes, Mérida.

Molinari, J., \& Soriano, P. (2014). Breeding and agestructure seasonality in Carollia brevicauda and other frugivorous bats (Phyllostomidae) in cloud forests in the Venezuelan Andes. Therya, 5, 81-109. DOI: 10.12933/therya-14-179

Monasterio, M. \& Reyes, S. (1980). Diversidad ambiental y variación de la vegetación en los páramos de los Andes Venezolanos. M. Monasterio (Ed.), Estudios Ecológicos en los Páramos Andinos (pp. 47-91). Mérida: Editorial de la Universidad de Los Andes.

Opler, P. A., Frankie, G. W., \& Baker, H. G. (1980). Comparative phenological studies of treelet and shrub species in tropical wet and dry forests in the lowlands of Costa Rica. Journal of Ecology, 68, 167-188. DOI: $10.2307 / 2259250$

Ortega, J., \& Castro-Arellano, I. (2001). Artibeus jamaicensis. Mammalian Species, 662, 1-9. DOI: 10.1644/1545-1410(2001)662\%3C0001:AJ\%3E2.0. $\mathrm{CO} ; 2$

R Core Team. (2015). R: A language and environment for statistical computing. R Foundation for Statistical Computing, Vienna, Austria. Retrieved from https:// www.R-project.org/

Racey, P. A. (1982). Ecology of bat reproduction. In T. H. Kunz (Ed.), Ecology of bats (pp. 57-104). New York: Plenum Press. DOI: 10.1007/978-1-4613-3421-7_2

Racey, P. A. (2009). Reproductive assessment of bats. In T. H. Kunz, \& S. Parsons (Eds.), Ecological and behavioral methods for the study of bats ( $2^{\text {nd }}$ ed., pp. 249264). Maryland: The Johns Hopkins University Press.

Racey, P. A., \& Entwistle, A. C. (2000). Life-history and reproductive strategies of bats. In E. G. Crichton, \& P. H. Krutzsch (Eds.), Reproductive biology of bats (pp. 364-414). New York: Academic Press. DOI: 10.1016/ B978-012195670-7/50010-2

Ramoni-Perazzi, P., Muñoz-Romo, M., Chaves, L. F., \& Kunz, T. H. (2012). Range prediction for the Giant Fruit-Eating Bat, Artibeus amplus (Phyllostomidae: Stenodermatinae) in South America. Studies on Neotropical Fauna and Environment, 47, 87-103.

Ramoni-Perazzi, P., Ruiz-Ramoni, D., Muñoz-Romo, M., Thielen Engelbertz, D., \& Soto Werschitz, I. A. (2014). Some considerations on the conservation status of the giant fruit-eating bat, Artibeus amplus 
(Phyllostomidae: Stenodermatinae). Interciencia, 39, 354-356.

Ruiz-Ramoni, D. (2010). Patrón reproductivo y dieta del murciélago frugivoro, Artibeus amplus (Chiroptera: Phyllostomidae), en una cueva cercana a Pregonero, Edo. Táchira-Venezuela. (Licenciatura). Universidad de Los Andes, Mérida.

Ruiz-Ramoni, D., Muñoz-Romo, M., Ramoni-Perazzi, P., Aranguren, Y., \& Fermin, G. (2011). Folivory in the giant fruit-eating bat Artibeus amplus (Phyllostomidae): a non-seasonal phenomenon. Acta Chiropterologica, 13, 195-199.

Sikes, R. S., Gannon, W. L., \& the Animal Care and Use Committee of the American Society of Mammalogists. (2011). Guidelines of the American Society of Mammalogists for the use of wild mammals in research. Journal of Mammalogy, 92, 235-253. DOI: 10.1644/10-MAMM-F-355.1

Sobral, G. L., \& Machado, I. C. (2001). Fruiting phenology and seed dispersal syndromes in caatinga, a tropical dry forest in the northeast of Brazil. Journal of Tropical Ecology, 17, 303-321.

Sosa, M. (1991). Relaciones ecológicas entre el murciélago Glossophaga longirostris y las cactáceas columnares en el bolsón árido de Lagunillas, Mérida, Venezuela (Licenciatura). Universidad de Los Andes, Mérida.

Sosa, M., \& Ramoni-Perazzi, P. (1995). Patrón reproductivo de Artibeus jamaicensis Leach, 1821 y A. lituratus (Olfers, 1818) (Chiroptera: Phyllostomidae) en una zona árida de Los Andes venezolanos. Revista Brasileira de Biología, 55, 705-713.

Sosa, M., \& Soriano, P. (1996). Resource availability, diet and reproduction in Glossophaga longirostris (Mammalia: Chiroptera) in an arid zone of the Venezuelan Andes. Journal of Tropical Ecology, 12, 805-818. DOI: $10.1017 / \mathrm{S} 0266467400010063$
Speakman, J. R. 2008. The physiological costs of reproduction in small mammals. Philosophical Transactions of the Royal Society B: Biological Sciences, 363, 375-398. DOI: $10.1098 /$ rstb.2007.2145

Taylor, M. A., \& Alfaro, E. J. (2005). Central America and the Caribbean, Climate of. In J. E. Oliver (Ed.), Encyclopedia of World Climatology. Encyclopedia of Earth Sciences Series (pp. 183-1988). Holanda: Springer Dordrecht.

Vela-Vargas, I. M. (2013). Variaciones en la fenología reproductiva de las especies de murciélagos en dos sistemas ganaderos: efecto de la disponibilidad de recurso (Tesis de Maestría). Pontificia Universidad Javeriana, Bogotá.

Willig, M. R. (1985). Reproductive patterns of bats from Caatingas and Cerrado Biomes in Northeast Brazil. Journal of Mammalogy, 66, 668-681. DOI: $10.2307 / 1380793$

Wilson, D. E. (1979). Reproductive patterns. In R. J. Baker, J. K. Jones, Jr., \& D. C. Carter (Eds.), Biology of Bats of the New World Family Phyllostomatidae, Part III. Special Publications of The Museum, Texas Tech University, 16, 317-378.

Wilson, D. E., Handley, C. O., Jr., \& Gardner, A. L. (1991). Reproduction on Barro Colorado Island. In C. O. Jr. Handley, D. E. Wilson, \& A. L. Gardner (Eds.), Demography and natural history of the common fruit bat, Artibeus jamaicensis, on Barro Colorado Island, Panama (pp. 43-52). Washington, D. C.: Smithsonian Contributions to Zoology 511, Smithsonian Institution Press.

Zortéa, M. (2003). Reproductive patterns and feeding habits of three nectarivorous bats (Phyllostomidae: Glossophaginae) from the Brazilian Cerrado. Brazilian Journal of Biology, 63, 159-168. DOI: 10.1590/ S1519-69842003000100020 